\title{
CORPORATE SOCIAL RESPONSIBILITY PERCEIVED BY EMPLOYEES: LATVIAN SURVEY RESULTS
}

\author{
Titko, J., Skvarciany, V., Tambovceva, T.
}

Jelena Titko / EKA University of Applied Sciences, Lomonosova str. 1/5, LV-1019, Riga, Latvia. Email: jelena.titko@eka.edu.Iv

Viktorija Skvarciany / Vilnius Gediminas Technical University, Faculty of Business Management, Sauletekio ave.11, LT-10223 Vilnius, Lithuania.Email: viktorija.skvarciany@vilniustech.It

Tatjana Tambovceva / Riga Technical University, Faculty of Engineering Economics and Management, Kalnciema str.6, LV-1048, Riga, Latvia.Email: tatjana.tambovceva@rtu.Iv

\section{Abstract}

There is empirical evidence that business commitment to the Corporate Social Responsibility (CSR) principles has a direct positive impact on customer loyalty, employees' performance, and, as a result, on the company's value. The goal of the current paper is to evaluate the perceived importance of the company's CSR-related practices from the viewpoint of employees. One hundred nineteen representatives of Latvian companies were surveyed, using the authors' developed questionnaire consisted of 35 statements. Survey data was processed applying the frequency analysis and the logistic regression method. Most of the respondents (84\%) perceive the company's commitment to CSR principles as necessary. The base on the frequency analysis results, the most important CSR elements from the viewpoint of Latvian employees are paid leaves, consumer interests, and salary. Logistic regression yielded the elements, which contribute the most to the positive perception of CSR: 'flexible work', 'support staff relaxation' and 'claims submission system' within the group' staff matters'. The measurement scale was tested for reliability and, based on Cronbach alpha results, was accepted as appropriate for use in a cross-country survey.

Implications for Central European audience: Despite the high interest in CSR-related issues in academia, the number of published works in Baltic countries is limited. In this particular study, the authors tried to identify — what exactly affects employees' positive attitude to CSR commitment - the company's participation in charity programmes or its environmental responsibility, for example? This survey contributed to the theoretical knowledge base about CSR perception among the staff of Latvian companies. In turn, the future survey is planned to be extended, involving respondents from Central and Eastern European countries. This, in turn, will allow making conclusions about the differences in attitude to CSR practices expressed by employees from different countries.

Keywords: corporate social responsibility; employees' perception; logistic regression; Latvia JEL Classification: M14 


\section{Introduction}

CSR has gained much attention from scholars during the last decade. Scientists claim that CSR could be treated as an opportunity to strengthen business activities (Du et al., 2010; Mercadé-Melé et al., 2018). CSR 'appears to reduce staff turnover, while increasing both customer satisfaction and reputation levels' (Galbreath, 2010, p. 423).

The number of scientific papers devoted to the issues related to socially responsible business, CSR, and business ethics has significant growth during the last decades. Search for keywords 'corporate social responsibility' yields more than 100000 results in the SCOPUS database. Within the framework of the current study, the authors intend to identify the most critical CSR elements/aspects perceived by staff. Considering the multidimensionality of the CSR concept, the authors are curious about what exactly is essential for staff members - the company's participation in charity programmes or its environmental responsibility, for example?

The goal of the given paper is to evaluate the perceived importance of the company's CSRrelated practices from the viewpoint of employees represented in Latvian companies. Besides, the measurement scale was tested for reliability in order to use it in a future crosscountry survey.

The online survey was conducted using the authors' developed research instrument (questionnaire). In total, 119 respondents - employed Latvian citizens - participated in the survey.

The reliability of the research instrument was assessed based on Cronbach alpha calculation's results. Conclusions about the most critical CSR aspects from the viewpoint of employees were made, applying such methods as frequency analysis and logistic regression method.

The research revealed that 'paid leaves', 'staff motivation system', and 'flexible work' (elements from the groups 'Staff financial support' and 'Staff matters') are essential CSR elements for respondents. Besides, the elements with a high value of perceived importance were the company's commitment to customer interests and ethical and honest way of doing business.

\section{Concept of Corporate Social Responsibility}

The development of the concept of Corporate Social Responsibility (CSR) has more than 60 years of history. Since the 1950s, it was investigated by many researchers in the different fields and relation with other concepts, such as company's performance (Mallin et al., 2014; Maqbool \& Zameer, 2018; Platonova et al., 2018; Rodriguez-Fernandez, 2016), customer satisfaction and loyalty (Aramburu \& Pescador, 2019; Chang \& Yeh, 2017; S. Lee \& Heo, 2009), corporate image (Maruf \& Afeez, 2014), employee satisfaction and loyalty (Bauman \& Skitka, 2012). Besides, the researchers pay attention to the questions regarding the perception of CSR by the company's employees, managers and top executives (Amran \& Nejati, 2014; Tambovceva et al., 2017; Verina et al., 2018).

Defining the concept of CSR, the authors of the given paper follow the definition provided by Ismail (2009, p. 199): '[CSR] is a concept whereby business organisations consider the interest of society by taking responsibility for the impact of their activities on customers, 
suppliers, employees, shareholders, communities and other stakeholders as well as their environment.' European Commission's (European Commission, 2011) definition is shorter but expresses the core of the concept: '... whereby companies integrate social and environmental concerns in their business operations and their interaction with their stakeholders voluntarily'.

Company's commitment to socially responsible business principles is resulted in (Asemah et al., 2013; S. J. Brammer \& Pavelin, 2006; S. Brammer \& Millington, 2005; Galbreath, 2010; Księżak, 2017):

- Improved corporate reputation and better brand recognition.

- More exceptional ability to attract talents.

- Increased job satisfaction and reduced employee turnover.

- Cost reduction and an increase in corporate performance.

- Increased sales and customer loyalty.

- Attracting new customers.

- Improved relations with the investment community and better access to capital.

- Stronger relations within communities through stakeholder engagement.

- Reducing environmental impact.

- Increased innovative potential.

Analysing the concept of corporate social responsibility, different scholars and practitioners emphasise the role of various CSR components (Table 1).

Table 1 | Dimensions and components of CSR

Dimensions/components of CSR

Based on Carroll (1991)

- $\quad$ economic components

- legal components

- ethical components

- $\quad$ philanthropic components

Based on Campbell (2007)

- $\quad$ employees' wages

- $\quad$ benefits for employees

- level of workplace safety

- $\quad$ product quality

- $\quad$ truth in advertising and pricing

- $\quad$ supplier relations

- working according to legislation

- community development and investment in it

- $\quad$ protection of environment 
Based on Chahal and Sharma (2006):

- $\quad$ operational support (undertaking operations ethically and with integrity)

- $\quad$ employees support (such as safety, job security, profit sharing, employee participation, treating employees fairly and equitably)

- community support (actively involved in education, health and housing-related supportive activities, co-opting activities, philanthropic activities)

- $\quad$ product/services (such as product/service quality, product safety, delivery, research, and development)

- environment support (such as sustaining the eco-friendly environment, producing environmentfriendly products, waste management, recycling)

- $\quad$ miscellaneous support (active participation in non-native country development)

Based on Lin and Hsu (2018)

- environmental protection

- ethical behaviour

- fair treatment of employees

- $\quad$ reducing consumer price sensitivity

- facilitating corporates to establish intangible assets

- mitigating the likelihood of the legislative procedure

- increasing the buying intention of socially conscious consumers

- $\quad$ attracting economic resources from socially responsible investors

- human rights

- environment

- community

- employee relations,

- corporate governance

- business behaviours toward customers and suppliers

Based on Rahman (2011)

- $\quad$ obligation to society

- $\quad$ stakeholders' involvement

- improving the quality of life

- economic development

- $\quad$ ethical business practice

- law-abiding

- voluntariness

- human rights

- $\quad$ protection of environment

- $\quad$ transparency \& accountability

Source: authors

The development of the research instrument was based on the CSR structure proposed by the World Business Council for Sustainable Development (Hohnen \& Potts, 2007, p. 4). CSR practices refer to 'commitments and activities pertaining to:

- $\quad$ corporate governance and ethics;

- $\quad$ health and safety;

- environmental stewardship;

- human rights (including core labour rights);

- $\quad$ sustainable development;

- conditions of work (including safety and health, hours of work, wages);

- industrial relations;

- community involvement, development and investment;

- $\quad$ involvement of and respect for diverse cultures and disadvantaged peoples;

- corporate philanthropy and employee volunteering; 
- $\quad$ customer satisfaction and adherence to principles of fair competition;

- $\quad$ anti-bribery and anti-corruption measures;

- $\quad$ accountability, transparency and performance reporting;

- $\quad$ supplier relations, for both domestic and international supply chains.'

Besides, the authors take into account the structure of non-financial reporting according to the Directive 2014/95/EU of the European Parliament and of the Council of 22 October 2014 (EU, 2014). The Directive regarding the disclosure of non-financial and diversity information requires an obligatory, including the information:

- $\quad$ regarding environmental matters - 'details of the current and foreseeable impacts of the undertaking's operations on the environment, and, as appropriate, health and safety, the use of renewable and/or non-renewable energy, greenhouse gas emissions, water use and air pollution.'

- $\quad$ regarding social and employee-related matters - 'the actions are taken to ensure gender equality... working conditions, social dialogue, respect for the right of workers ..., respect for trade union rights, health and safety at work and the dialogue with local communities.'

- regarding human rights, anti-corruption and bribery - '...information on the prevention of human rights abuses and/or on instruments in place to fight corruption and bribery.'

Developing the structure of the questionnaire and formulating the statements, in addition to the above-mentioned sources, the authors also used the statements from the questionnaire used within the survey 'Comparing the state of CSR in Baltics and Finland' (Alijošiutè, 2015).

Formulation of the research hypothesis stated by the authors was based on the analysis of the scientific publications devoted to the issues regarding employees' perception of CSR. A wide range of studies investigates different aspects of employees' attitude towards CSR practices, as well as its link to staff work engagement, job satisfaction (Azim et al., 2014; Farid et al., 2019; Mascarenhas et al., 2020; Reklitis et al., 2018; Tahlil Azim, 2016) and job performance (Lee et al., 2013; Sarfraz et al., 2018). Some papers focus on factors affecting employees' perception of CSR (Bravo et al., 2017; Gkorezis \& Petridou, 2017; Rosati et al., 2018; Melovic et al., 2019).

The topic of employees' attitudes to specific CSR aspects is less popular among the researchers, and it was the reason to conduct the current research. Zientara et al. (2015) investigate 'self-related' CSR experiences and 'others-related' CSR experiences. But again, they do not assess the perceived importance of 'experiences' but look at them through the prism of the relationship with job satisfaction, organisational commitment, and work engagement.

Soroka and Mazurek-Kusiak (2014) and Ersoy (2015) focus on CSR elements essential for potential employees, thus, assess the 'CSR activities in attracting talent'. Choosing an employer, respondents highlight the importance of the 'proposed salary', 'working atmosphere', 'workplace environment' (Hafee et al., 2019; Soroka \& Mazurek-Kusiak, 2014). 
Attitude to employees ('work-life balance', 'employee support programs') is essential for job seekers (Ersoy, 2015).

The authors intend to test the assumption that 'self-related' CSR activities are more important for employees than other aspects. Thus, the research hypotheses were stated as follows:

$\mathrm{H} 1$ : For Latvian respondents, the most important CSR aspects are those related to staff financial support (such as motivation system, medical allowance, pension) and those related to the company's attitude to employees (such as job security, team building, staff training).

\section{Methodology}

The questionnaire developed by the authors' was distributed randomly through social networks. The structure of the questionnaire is reflected in Table 2.

Table 2 | Structure of the questionnaire

\begin{tabular}{|c|c|c|}
\hline Label & Question & Type of the question: responses \\
\hline A_Q1 & Gender & Closed: 2 alternative responses (male; female) \\
\hline A_Q2 & Year of birth & $\begin{array}{l}\text { Closed: } 4 \text { alternative responses (1946-1964; 1965-1980; } \\
\text { 1981-2000; } 2001 \text { and later) }\end{array}$ \\
\hline A_Q3 & $\begin{array}{l}\text { Represented sector } \\
\text { of the economy }\end{array}$ & $\begin{array}{l}\text { Closed: } 11 \text { alternative responses (main sectors + option } \\
\text { 'other') }\end{array}$ \\
\hline B_Q1 & $\begin{array}{l}\text { Overall perceived } \\
\text { importance of CSR }\end{array}$ & Closed: Evaluation with a 5-point scale \\
\hline B_Q2 & $\begin{array}{l}\text { Operating period in } \\
\text { the market }\end{array}$ & $\begin{array}{l}\text { Closed: } 35 \text { elements of CSR, perceived importance (5-point } \\
\text { scale) }\end{array}$ \\
\hline
\end{tabular}

Source: authors

One hundred nineteen respondents participated in the survey (64\% females, $36 \%$ males). The only representatives of generation $X$ (birth years 1965-1980) and generation $Y$ (the birth year 1981-2000) were among the participants. Most respondents were employed in the Education sector and Construction sector (18\% and $20 \%$, respectively).

The choice of options in A_Q2 question was based on the authors' assumption about the different attitudes to CSR among representatives of different generations (baby boomers, millennials and etc.). However, this assumption was not tested within the current study.

B part included B_Q1 question that was aimed to determine the attitude towards CSR among employees with no particular specification of the elements. Data B_Q1 was a dependent variable for the logistic regression model. B_Q2 question involved 35 CSR elements, which were offered for evaluation to the respondents. The proposed evaluation scale was a Likerttype 5-point scale from ' 1 ' (absolutely not important) to '5' (extremely important).

For testing the reliability of the instrument, B_Q2 statements were analysed, using a reliability analysis option with an application of the Cronbach's alpha test. All the statements were initially grouped by the authors into six categories: 1) strategic vision and transparency, 2) honest business principles, 3) customers and community, 4) staff financial support, 5) staff matters, 6) environment. The results of reliability testing are provided in Table 3. 
Table 3 | Test for the reliability of B_Q2 scale Labels for B_Q2 statements

Corrected Item-Total

Correlation

Strategic vision and transparency

\begin{tabular}{lll}
\hline Strategy $\left(\mathrm{X}_{1}\right)$ & 0.542 & 0.966 \\
Tax transparency $\left(\mathrm{X}_{2}\right)$ & 0.739 & 0.965 \\
Code of ethics $\left(\mathrm{X}_{3}\right)$ & 0.816 & 0.965 \\
Information provision $\left(\mathrm{X}_{4}\right)$ & 0.638 & 0.966 \\
\hline
\end{tabular}

Honest business principles

\begin{tabular}{lll}
\hline Salary $\left(X_{5}\right)$ & 0.564 & 0.966 \\
Taxes $\left(X_{6}\right)$ & 0.557 & 0.966 \\
Business honesty $\left(X_{7}\right)$ & 0.764 & 0.965 \\
Anti-corruption $\left(X_{8}\right)$ & 0.637 & 0.966 \\
Partners $\left(X_{9}\right)$ & 0.734 & 0.965 \\
\hline
\end{tabular}

Customers and community

\begin{tabular}{|c|c|c|}
\hline Data security $\left(\mathrm{X}_{10}\right)$ & 0.616 & 0.966 \\
\hline Consumer interests $\left(X_{11}\right)$ & 0.602 & 0.966 \\
\hline Customer claims $\left(X_{12}\right)$ & 0.671 & 0.965 \\
\hline $\begin{array}{l}\text { Sustainable consumption, awareness } \\
\text { raising }\left(X_{13}\right)\end{array}$ & 0.763 & 0.965 \\
\hline Support to local community $\left(\mathrm{X}_{14}\right)$ & 0.645 & 0.966 \\
\hline Cooperation with NGO $\left(X_{15}\right)$ & 0.705 & 0.965 \\
\hline Social programmes $\left(\mathrm{X}_{16}\right)$ & 0.612 & 0.966 \\
\hline \multicolumn{3}{|c|}{ Staff financial support } \\
\hline Staff motivation system $\left(\mathrm{X}_{17}\right)$ & 0.552 & 0.966 \\
\hline Paid leaves $\left(X_{18}\right)$ & 0.647 & 0.966 \\
\hline Medical insurance $\left(X_{19}\right)$ & 0.465 & 0.966 \\
\hline Family support $\left(\mathrm{X}_{20}\right)$ & 0.605 & 0.966 \\
\hline Pension $\left(\mathrm{X}_{21}\right)$ & 0.600 & 0.966 \\
\hline
\end{tabular}

Staff matters

\begin{tabular}{|c|c|c|}
\hline Flexible work $\left(\mathrm{X}_{22}\right)$ & 0.413 & 0.967 \\
\hline Equality $\left(\mathrm{X}_{23}\right)$ & 0.591 & 0.966 \\
\hline Work security and stress-reducing $\left(\mathrm{X}_{24}\right)$ & 0.717 & 0.965 \\
\hline Support staff relaxation $\left(\mathrm{X}_{25}\right)$ & 0.644 & 0.966 \\
\hline Team building $\left(\mathrm{X}_{26}\right)$ & 0.619 & 0.966 \\
\hline Staff training $\left(\mathrm{X}_{27}\right)$ & 0.590 & 0.966 \\
\hline Claims submission system $\left(\mathrm{X}_{28}\right)$ & 0.675 & 0.965 \\
\hline Job satisfaction assessment $\left(\mathrm{X}_{29}\right)$ & 0.761 & 0.965 \\
\hline \multicolumn{3}{|c|}{ Environment } \\
\hline Resource-saving $\left(\mathrm{X}_{30}\right)$ & 0.759 & 0.965 \\
\hline Waste reduction $\left(\mathrm{X}_{31}\right)$ & 0.769 & 0.965 \\
\hline Waste management $\left(X_{32}\right)$ & 0.772 & 0.965 \\
\hline Environment-friendly technologies $\left(\mathrm{X}_{33}\right)$ & 0.794 & 0.965 \\
\hline Environmental impact assessment $\left(X_{34}\right)$ & 0.747 & 0.965 \\
\hline Environment-friendly processes $\left(X_{35}\right)$ & 0.800 & 0.965 \\
\hline
\end{tabular}

Source: authors 
Cronbach alpha for the whole scale is equal to 0.966 , which indicates an excellent overall consistency. The removal of $\mathrm{X}_{22}$ can increase the value of alpha for 0.001 points that could be treated as an insignificant result. Thus, the scale was not changed.

Before running a logistic regression, the data gathered during the survey was tested for normality, as this is a critical factor for choosing the research method. For testing the normality, the Shapiro-Wilk test was employed, and the results showed that all the variables are non-parametric, i.e. the null hypothesis is rejected, and all the variables do not follow the normal distribution. Based on that, non-parametric regression was chosen for analysing the data in order to test the predictive quality of the proposed models.

In order to find out which of the elements of each group has the most significant impact on the overall attitude towards organisations' work in line with CSTR principles, the logistic regression was employed. The main idea of logistic regression is that it shows which of the analysed elements influence the possibility of the dependent variable to take the value of one. In the current study, $Y=1$ means that for the respondents, it is essential that the organisation perform following CSR principles, and $Y=0$ means that CSR principles are not necessary for the respondents. The logistic regression model is presented below:

$$
\ln \left(\frac{\mathbb{P}(Y=1)}{\mathbb{P}(Y=0)}\right)=\beta_{0}+\sum_{i=1}^{n} \beta_{i} x_{i},
$$

where $Y=1$ - for respondents, it is vital if their organisation follows CSR principles;

$Y=0-$ for respondents, it is not crucial if their organisation supports CSR principles;

$\beta_{0}$ - intercept;

$\beta_{i}(i=1,2, \ldots, n)-$ coefficient associated with independent variables $x_{1}, x_{2}, \ldots, x_{n}$.

For testing the quality of the model Nagelkerke pseudo- $\mathrm{R}^{2}$ and chi-square tests were used. Moreover, it is worth mentioning that logistic regression could be used only if the dependent variable lies on a dichotomous scale; hence the values of the dependent variable were transformed (' 1 ' and ' 2 ' were set to zero; ' 4 ' and ' 5 ' - to ' 1 '). The answers of the respondents who assessed their attitude towards CSR at three were removed from the survey. Consequently, the final number of respondents for the logistic regression analysis was 107.

\section{Results}

Over attitude to CSR activities is quite positive among the respondents. Answering the general question 'How important is that your current or potential employer acts according to CSR principles?', 84\% of survey participants responded 'important' or 'extremely important'.

Analysing each element of B_Q2 separately, the most important for the respondents are summarised in Table 4. Perceived importance was calculated as a percentage of respondents, evaluating a particular element as 'important' or 'extremely important'. 
Table 4 | The most important CSR elements from the viewpoint of employees

\begin{tabular}{llll}
\hline CSR element & $\begin{array}{l}\text { Perceived } \\
\text { importance }\end{array}$ & CSR element & $\begin{array}{l}\text { Perceived } \\
\text { importance }\end{array}$ \\
\hline Paid leaves & $93.28 \%$ & Flexible work & $87.39 \%$ \\
Consumer interests & $91.60 \%$ & Business honesty & $86.55 \%$ \\
Salary & $89.08 \%$ & Equality & $86.55 \%$ \\
Taxes & $87.39 \%$ & Strategy & $85.71 \%$ \\
Data security & $87.39 \%$ & Staff training & $84.03 \%$ \\
Staff motivation & & & \\
system & $87.39 \%$ & Medical insurance & $81.51 \%$ \\
\hline
\end{tabular}

Source: authors

The most critical elements within each group according to their perceived importance are presented in Figure 1. The only elements that were evaluated as 'important' or 'extremely important' by more than $80 \%$ of respondents were included. The exception is the element 'Environment-friendly technologies'; $64 \%$ of respondents assessed it at '4' and '5', but it was the most important in the group 'Environment'.

Figure 1 | Most critical elements of CSR based on the perceived importance
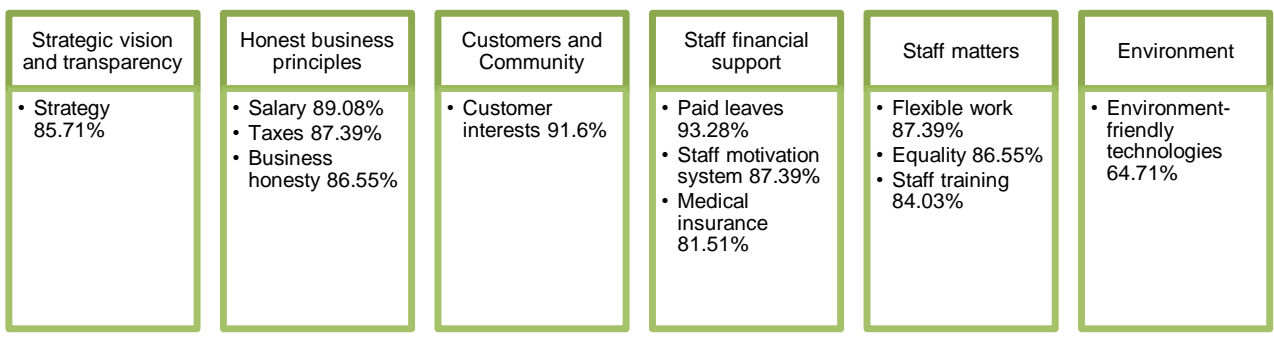

Source: authors

For the purpose of in-depth analysis of the employees' attitude towards CSR, six groups of elements were tested (see Table 5). For each group, the logistic regression model was developed. Before presenting the models themselves, the goodness of fit of each model is presented.

Table 5 | The goodness of fit for logistic regression models

\begin{tabular}{lllll}
\hline Group of elements & $\begin{array}{l}\text { Nagelkerke } \\
\text { pseudo-R }\end{array}$ & Statistic & $\begin{array}{l}\text { Chi- } \\
\text { square }\end{array}$ & Pr $>\mathbf{C h}^{\mathbf{2}}$ \\
\hline $\begin{array}{l}\text { Strategic vision and } \\
\text { transparency }\end{array}$ & 0.392 & -2 Log(Likelihood) & 17.437 & 0.002 \\
$\begin{array}{l}\text { Honest business } \\
\text { principles }\end{array}$ & 0.615 & -2 Log(Likelihood) & 28.648 & $<0.0001$ \\
$\begin{array}{l}\text { Customers } \\
\text { Staff financial support }\end{array}$ & 0.670 & $-2 \log ($ Likelihood) & 31.652 & $<0.0001$ \\
$\begin{array}{l}\text { Staff matters } \\
\text { Environment }\end{array}$ & 1.000 & -2 Log(Likelihood) & 16.246 & 0.006 \\
\hline
\end{tabular}

Source: Authors' own calculations

As it could be seen from the table above, all the probabilities are lower than 0.05 , which means that all the variables bring essential information to the models. Moreover, Nagelkerke pseudo- $R^{2}$ in all the cases is higher than 0.25 , illustrating the explanatory strength of the 
variables. Summing up, all the models have passed the quality tests and could be used. The developed models are presented in Table 6.

Table 6 | Developed logistic regression models

\begin{tabular}{|c|c|c|}
\hline $\begin{array}{l}\text { Group of } \\
\text { elements }\end{array}$ & Model & \\
\hline $\begin{array}{l}\text { Strategic vision } \\
\text { and transparency }\end{array}$ & $\ln \left(\frac{\mathbb{P}(Y=1)}{\mathbb{P}(Y=0)}\right)=-3.905+\mathbf{0 . 5 9 4} X_{1}-0.127 X_{2}+\mathbf{0 . 9 1 6} X_{3}+\mathbf{0 . 9 4} X_{4}$ & (2) \\
\hline $\begin{array}{l}\text { Honest business } \\
\text { principles }\end{array}$ & $\ln \left(\frac{\mathbb{P}(Y=1)}{\mathbb{P}(Y=0)}\right)=-6.571+\mathbf{1 . 4 3 0} X_{5}+\mathbf{1 . 4 7 9} X_{6}-0.768 X_{7}+\mathbf{0 . 5 7 3} X_{\mathbf{8}}+\mathbf{0 . 2 1 7} X_{9}$ & (3) \\
\hline $\begin{array}{l}\text { Customers and } \\
\text { community }\end{array}$ & $\begin{array}{l}\ln \left(\frac{\mathbb{P}(Y=1)}{\mathbb{P}(Y=0)}\right)=-7.974+\mathbf{3 . 4 4 6} X_{10}-2.102 X_{11}+\mathbf{1 . 1 7 1} X_{\mathbf{1 2}}-0.114 X_{13}+ \\
\mathbf{2 . 0 8 3 X _ { 1 4 }}-1.771 X_{15}+\mathbf{0 . 6 9 9} X_{\mathbf{1 6}}\end{array}$ & $(4)$ \\
\hline $\begin{array}{l}\text { Staff financial } \\
\text { support }\end{array}$ & $\begin{array}{l}\ln \left(\frac{\mathbb{P}(Y=1)}{\mathbb{P}(Y=0)}\right)=-2.791+\mathbf{0 . 4 8 9} \boldsymbol{X}_{17}+\mathbf{0 . 7 0 5} \boldsymbol{X}_{\mathbf{1 8}}+\mathbf{0 . 4 7 1} \boldsymbol{X}_{\mathbf{1 9}}-1.928 X_{20}+ \\
\mathbf{1 . 6 7 2 X _ { 2 1 }}\end{array}$ & (5) \\
\hline Staff matters & $\begin{array}{l}\ln \left(\frac{\mathbb{P}(Y=1)}{\mathbb{P}(Y=0)}\right)=-243.770+\mathbf{1 5 . 1 2 1} X_{22}-4.442 X_{23}-38.285 X_{24}+\mathbf{1 1 3 . 3 6 0} X_{25}- \\
29.273 X_{26}+\mathbf{5 . 3 5 0} X_{27}+\mathbf{4 7 . 0 3 9} X_{28}+\mathbf{4 . 9 2 8} X_{29}\end{array}$ & (6) \\
\hline Environment & $\begin{array}{l}\ln \left(\frac{\mathbb{P}(Y=1)}{\mathbb{P}(Y=0)}\right)=-3.369+\mathbf{1 0 . 5 6 9} X_{30}-1.494 X_{31}+\mathbf{0 . 1 9 3} X_{32}+\mathbf{0 . 5 4 0} X_{33}- \\
6.394 X_{34}+\mathbf{0 . 0 7 8} X_{35}\end{array}$ & (7) \\
\hline
\end{tabular}

Source: Authors' own calculations

Within the group 'Strategic vision and transparency' (equation 2), the most influential element is a 'code of ethics' $\left(\mathrm{X}_{3}\right)$. 'Strategy' $\left(\mathrm{X}_{10}\right)$ and 'information provision' are also the elements that increase the overall importance of CSR; meanwhile, 'tax transparency' $\left(X_{2}\right)$ increases the probability that CSR will not be essential for employees (negative relationship). Analysis of the group 'Honest business principles' showed that 'salary' $\left(X_{5}\right)$ and 'taxes' $\left(X_{6}\right)$ are the most critical elements that raise the probability of a positive attitude towards CSR among employees. In the case of the 'Customers and community' group, the elements that contribute to the likelihood that for respondents, the overall view on CSR is positive are 'data security' $\left(X_{10}\right)$, 'consumer interests' $\left(X_{11}\right)$ and 'support to the local community' $\left(X_{14}\right)$. While analysing the 'Staff financial support' group, the study revealed that the element influencing the probability of CSR importance for employees is a 'pension' $\left(X_{21}\right)$. The surprising result is that 'family support' has a negative relationship with overall CSR perceived importance. Equation (6) revealed that 'support staff relaxation' $\left(X_{25}\right)$ remarkably influences the probability of $Y=1$, and its coefficient is 113.360. Regression coefficients for 'works security' and 'claims submission system' are high as well; it means that these elements contribute to the positive attitude on CSR. In the group 'Environment', the only element that positively affects $Y$ is 'resource-saving' $\left(\mathrm{X}_{30}\right)$.

\section{Conclusions}

The current paper reflects the results of the authors' conducted survey aimed to evaluate the perceived importance of the company's CSR-related practices from the viewpoint of employees. Different CSR elements combined in six groups (Strategic vision and 
transparency; Honest business principles, Customers and community; Staff financial support; Staff matters; Environment) were offered to 119 Latvian respondents for evaluation.

In general, Latvian respondents perceive a company's commitment to CSR principles as important (84\% of respondents). However, not all CSR elements are treated equally.

Ranking CSR elements according to their perceived importance, the study revealed the top ten the most critical items from all the groups, excluding 'Environment'. Top 3 includes 1) paid leaves - related statement 'a company provides employees with paid leave (for instance, study leave, leave for childcare)', 2) consumer interests - related statement 'a company takes into account consumer/customer interests', and 3) salary-related statement 'a company pays salary officially, no envelope salary'. These statements were evaluated as 'important' or 'extremely important' by $93 \%, 92 \%$, and $89 \%$ of respondents, respectively.

Environment-related elements (resource-saving, waste management, environment-friendly processes) were not prioritised, as well as a company's activities towards the support of the local community (cooperation with NGO, the company's support to society, charity programmes, sports, culture and etc.). Analysing the logistic regression models, within the group 'Environment', the only element 'Resource-saving' contributes significantly to $\mathrm{Y}$ (overall attitude to CSR).

The research hypothesis H1: 'For Latvian respondents, the most important CSR aspects are those related to staff financial support (such as motivation system, medical allowance, pension) and those related to company's attitude to employees (such as job security, team building, staff training)' is confirmed. TOP10 of the essential elements includes six items from the groups 'Staff financial support' and 'Staff matters'. Besides, regression analysis revealed the strong predicting power (the positive relationship between explanatory and dependent variables) of almost all the elements from these groups.

It is worth mentioning that an ethical and honest way of doing business is also perceived as necessary by the respondents. The statements 'a company pays salary officially, no envelope salary' $\left(X_{5}\right)$, 'a company pays taxes in a fair way' $\left(X_{6}\right)$ and 'a company is committed to honest business principles' $\left(\mathrm{X}_{7}\right)$ were included in TOP 10 of the essential CSR items. Besides, the elements 'customer interests' and 'data security' were evaluated at ' 4 ' and '5' by $91 \%$ and $87 \%$ of respondents, respectively.

As mentioned before, the researchers mostly investigate the relationship between CSR perception and employees' commitment to the company, work engagement and staff performance, as well as job satisfaction. That is why it is difficult to refer to the current research findings to previous results. Sometimes, the researchers treat CSR elements as non-CSR related attributes. For instance, 'job security' was ranked among the most critical factors influencing the choice of an organisation in the research conducted by Simpson and Aprim (2018), but it was not a CSR-related factor in contrast to the current study ('Work security and stress-reducing' $\left(\mathrm{X}_{24}\right)$ ). But it was also not prioritised by Latvian respondents.

The current research provides an insight into the general perception of CSR specific attributes and allows managers to understand which CSR practices can contribute to the attraction and retention of employees. Latvian respondents do not care about the company's environmental image, but business reputation and commitment to staff and customers interests matter. This 
goes in line with the conclusions made by Nedelko and Potocan (2019: that organisational expenses that are linked to CSR could be greater for social than environmental issues.

As for practical implications, the implementation of a claim submission system $\left(X_{28}\right)$ to ensure the up-to-down feedback and staff training system $\left(X_{27}\right)$ are quite crucial for Latvian employees (positive regression coefficients - equation (6)). Sometimes, these measures do not even require a significant financial contribution but only proper management.

The main limitation of the study is the sample size. The authors intend to conduct a crosscountry survey to increase the reliability of the results. Thus, the next step is expected to be a distribution of the developed questionnaire among the respondents in other countries (the potential geographical area is Baltic States, Central and Eastern Europe). The analysis of the received results will be based not only on the whole sample data but also on grouping respondents according to their represented generation and working sector.

\section{References}

Alijošiutè, A. (2015). Comparing state of CSR in Baltic states and Finland. Nordic CSR Summit. https://bit.ly/2YHdlTi.

Amran, A., \& Nejati, M. (2014). Corporate Social Responsibility Perception Among Developing Country SMEs: An Exploratory Study. In Developments in Corporate Governance and Responsibility (pp. 85-104). https://doi.org/10.1108/S2043-052320140000006003.

Aramburu, I. A., \& Pescador, I. G. (2019). The Effects of Corporate Social Responsibility on Customer Loyalty: The Mediating Effect of Reputation in Cooperative Banks Versus Commercial Banks in the Basque Country. Journal of Business Ethics, 154(3), 701-719. https://doi.org/10.1007/s10551-017-3438-1.

Asemah, E. S., Okpanachi, R. A., \& Edegoh, L. O. N. (2013). Business Advantages of Corporate Social Responsibility Practice: A Critical Review. New Media and Mass Communication, 18(0), 45-54. https://doi.org/10.7176/NMMC.VOL1845-54.

Azim, M. T., Diyab, A. A., \& Al-Sabaan, S. A. (2014). CSR, employee job attitude and behavior: Saudi bank experience. Transylvanian Review of Administrative Sciences, 43E, 25-47.

Bauman, C. W., \& Skitka, L. J. (2012). Corporate social responsibility as a source of employee satisfaction. Research in Organisational Behavior, 32, 63-86. https://doi.org/10.1016/j.riob.2012.11.002.

Brammer, S. J., \& Pavelin, S. (2006). Corporate Reputation and Social Performance: The Importance of Fit. Journal of Management Studies, 43(3), 435-455. https://doi.org/10.1111/j.14676486.2006.00597.x.

Brammer, S., \& Millington, A. (2005). Corporate Reputation and Philanthropy: An Empirical Analysis. Journal of Business Ethics, 61(1), 29-44. https://doi.org/10.1007/s10551-005-7443-4.

Bravo, R., Buil, I., Chernatony, L. de, \& Martínez, E. (2017). Brand Identity Management and Corporate Social Responsibility: an Analysis from Employees' perspective in the Banking Sector. Journal of Business Economics and Management, 18(2), 241-257. https://doi.org/10.3846/16111699.2016.1209785.

Campbell, J. L. (2007). Why would corporations behave in socially responsible ways? An institutional theory of corporate social responsibility. Academy of Management Review, 32(3), 946-967.

Carroll, A. B. (1991). The pyramid of corporate social responsibility: Toward the moral management of organisational stakeholders. Business Horizons, 34(4), 39-48. https://doi.org/10.1016/00076813(91)90005-G.

Chahal, H., \& Sharma, R. D. (2006). Implications of corporate social responsibility on marketing performance: A conceptual framework. Journal of Services Research, 6(1), 205-216. https://www.researchgate.net/publication/285854144. 
Chang, Y.-H., \& Yeh, C.-H. (2017). Corporate social responsibility and customer loyalty in intercity bus services. Transport Policy, 59, 38-45. https://doi.org/10.1016/j.tranpol.2017.07.001.

Du, S., Bhattacharya, C. B., \& Sen, S. (2010). Maximizing Business Returns to Corporate Social Responsibility (CSR): The Role of CSR Communication. International Journal of Management Reviews, 12(1), 8-19. https://doi.org/10.1111/j.1468-2370.2009.00276.x.

Ersoy, I. (2015). Effects of perceptions of corporate social responsibilityon employer attractiveness. Pressacademia, 2(4), 507-507. https://doi.org/10.17261/Pressacademia.2015414453.

European Commission. (2011). Corporate Social Responsibility: a new definition, a new agenda for action. https://ec.europa.eu/commission/presscorner/detail/en/MEMO_11_730.

Farid, T., Iqbal, S., Ma, J., Castro-González, S., Khattak, A., \& Khan, M. K. (2019). Employees' Perceptions of CSR, Work Engagement, and Organizational Citizenship Behavior: The Mediating Effects of Organizational Justice. International Journal of Environmental Research and Public Health, 16(10), 1731. https://doi.org/10.3390/ijerph16101731.

Galbreath, J. (2010). How does corporate social responsibility benefit firms? Evidence from Australia. European Business Review, 22(4), 411-431. https://doi.org/10.1108/09555341011056186.

Gkorezis, P., \& Petridou, E. (2017). Corporate social responsibility and pro-environmental behaviour: organisational identification as a mediator. European J. of International Management, 11(1), 1. https://doi.org/10.1504/EJIM.2017.10001677.

Hafee, I., Yingjun, Z., Hafeez, S., Mansoor, R., \& Rehman, K. U. (2019). Impact of Workplace Environment on Employee Performance: Mediating Role of Employee Health. Business, Management and Education, 17(2), 173-193. https://doi.org/10.3846/bme.2019.10379.

Hohnen, P., \& Potts, J. (2007). Corporate Social Responsibility: An Implementation Guide for Business. http://www.iisd.org.

Ismail, M. (2009). Corporate social responsibility and its role in community development: an international perspective. The Journal of International Social Research, 2(9), 199-209. https://www.researchgate.net/publication/40426284.

Księżak, P. (2017). The Benefits from CSR for a Company and Society. Journal of Corporate Responsibility and Leadership, 3(4), 53. https://doi.org/10.12775/JCRL.2016.023.

Lee, E. M., Park, S.-Y., \& Lee, H. J. (2013). Employee perception of CSR activities: Its antecedents and consequences. Journal of Business Research, 66(10), 1716-1724. https://doi.org/10.1016/j.jbusres.2012.11.008.

Lee, S., \& Heo, C. Y. (2009). Corporate social responsibility and customer satisfaction among US publicly traded hotels and restaurants. International Journal of Hospitality Management, 28(4), 635-637. https://doi.org/10.1016/j.ijhm.2009.02.007.

Lin, S.-J., \& Hsu, M.-F. (2018). Decision making by extracting soft information from CSR news report. Technological and Economic Development of Economy, 24(4), 1344-1361. https://doi.org/10.3846/tede.2018.3121.

Mallin, C., Farag, H., \& Ow-Yong, K. (2014). Corporate social responsibility and financial performance in Islamic banks. Journal of Economic Behavior \& Organization, 103, S21-S38. https://doi.org/10.1016/j.jebo.2014.03.001.

Maqbool, S., \& Zameer, M. N. (2018). Corporate social responsibility and financial performance: An empirical analysis of Indian banks. Future Business Journal, 4(1), 84-93. https://doi.org/10.1016/j.fbj.2017.12.002.

Maruf, A. A., \& Afeez, B. A. (2014). Corporate social responsibility and corporate image. Transnational Journal of Science and Technology, 4(2), 58-79.

Mascarenhas, C., Mendes, L., Marques, C., \& Galvão, A. (2020). Exploring CSR's influence on employees' attitudes and behaviours in higher education. Sustainability Accounting, Management and Policy Journal, 11(4), 653-678. https://doi.org/10.1108/SAMPJ-04-2018-0101.

Melovic, B., Milovic, N., Backovic-Vulic, T., Dudic, B., \& Bajzik, P. (2019). Attitudes and Perceptions of 
Employees toward Corporate Social Responsibility in Western Balkan Countries: Importance and Relevance for Sustainable Development. Sustainability, 11(23), 6763. https://doi.org/10.3390/su11236763.

Mercadé-Melé, P., Molinillo, S., Fernández-Morales, A., \& Porcu, L. (2018). CSR Activities and Consumer Loyalty: the Effect of the Type of Publicising Medium. Journal of Business Economics and Management, 19(3), 431-455. https://doi.org/10.3846/jbem.2018.5203.

Nedelko, Z., \& Potocan, V. (2019). Perception of Corporate Social Responsibility by the Employees. In Socio-Economic Development: Concepts, Methodologies, Tools, and Applications (pp. 1442 1465). IGI Global. https://doi.org/10.4018/978-1-4666-7294-9.ch003.

Platonova, E., Asutay, M., Dixon, R., \& Mohammad, S. (2018). The Impact of Corporate Social Responsibility Disclosure on Financial Performance: Evidence from the GCC Islamic Banking Sector. Journal of Business Ethics, 151(2), 451-471. https://doi.org/10.1007/s10551-016-3229-0.

Rahman, S. (2011). Evaluation of Definitions: Ten Dimensions of Corporate Social Responsibility. World Review of Business Research, 1(1), 166-176.

Reklitis, P., Trivellas, P., Mantzaris, I., Mantzari, E., \& Reklitis, D. (2018). Employee Perceptions of Corporate Social Responsibility Activities and Work-Related Attitudes: The Case of a Greek Management Services Organization. In Sustainability and Social Responsibility: Regulation and Reporting (pp. 225-240). Springer. https://doi.org/10.1007/978-981-10-4502-8_10.

Rodriguez-Fernandez, M. (2016). Social responsibility and financial performance: The role of good corporate governance. BRQ Business Research Quarterly, 19(2), 137-151. https://doi.org/10.1016/j.brq.2015.08.001.

Rosati, F., Costa, R., Calabrese, A., \& Pedersen, E. R. G. (2018). Employee attitudes towards corporate social responsibility: a study on gender, age and educational level differences. Corporate Social Responsibility and Environmental Management, 25(6), 1306-1319. https://doi.org/10.1002/csr.1640.

Sarfraz, M., Qun, W., Abdullah, M., \& Alvi, A. (2018). Employees' Perception of Corporate Social Responsibility Impact on Employee Outcomes: Mediating Role of Organizational Justice for Small and Medium Enterprises (SMEs). Sustainability, 10(7), 2429. https://doi.org/10.3390/su10072429.

Simpson, S. N. Y., \& Aprim, E. K. (2018). Do corporate social responsibility practices of firms attract prospective employees? Perception of university students from a developing country. International Journal of Corporate Social Responsibility, 3(1), 6. https://doi.org/10.1186/s40991-018-0031-6.

Soroka, A., \& Mazurek-Kusiak, A. (2014). The importance of corporate social responsibility of enterprisese in business. Oeconomia, 13(2), 117-125.

Tahlil Azim, M. (2016). Corporate Social Responsibility and employee behavior: mediating role of organisational commitment. Review of Business Management, 18, 207-225. https://doi.org/10.7819/rbgn.v18i60.2319.

Tambovceva, T., Titko, J., \& Alksne, A. (2017). Corporate Social Responsibility Perceived by Latvian Enterprises. Proceedings of the 30th International Business Information Management Association Conference, IBIMA 2017 - Vision 2020: Sustainable Economic Development, Innovation Management, and Global Growth, 1557-1568. https://ortus.rtu.Iv/science/en/publications/27714Corporate+Social+Responsibility+Perceived+by+Latvian+Enterprises.

Verina, N., Titko, J., \& Lejniece, I. (2018). Tax Governance as a Part of Corporate Social Responsibility. 10th International Scientific Conference "Business and Management 2018", 19-26. https://doi.org/10.3846/bm.2018.04.

Zientara, P., Kujawski, L., \& Bohdanowicz-Godfrey, P. (2015). Corporate social responsibility and employee attitudes: evidence from a study of Polish hotel employees. Journal of Sustainable Tourism, 23(6), 859-880. https://doi.org/10.1080/09669582.2015.1019511.

The research paper passed the review process. | Received: 28 June, 2020; Revised: 28 July, 2020; Accepted: 18 August, 2020; Pre-published online: 22 December, 2020; Published in the regular issue: 2 July, 2021. 